\title{
ENHANCEMENT OF HEAT TRANSFERRED RATE THROUGH HEAT EXCHANGERS DURING CONCENTRATION PROCESS OF MILK
}

\author{
Said Elshahat Abdallah ${ }^{1}$ and Wael Mohamed Elmessery ${ }^{2}$
}

\section{ABSTRACT}

Fouling problems of heat exchangers affect severely the performance of heat transfer process during the concentration of milk. In this investigation the strategy of anti-fouling is focused on investigate the optimal hydrodynamic flow. Two combined techniques, for resulting oscillating high values of shear stress on heat transfer surfaces, were applied in the current investigation. The two techniques are dissolved air flotation for microbubbles generation in the milk stream with pulsed flow for hydrodynamics conditions modifications. Four different applied air pressures of 0.1,0.2, 0.3, and 0.6MPa for controlling the microbubbles discharge and three modes of pulsation were nominated as uniform pulsation, gradient pulsation and without pulsation. Plate heat exchanger used commonly in milk industry for thermal treatments. Commercial pilot scale of plate heat exchanger was operated at milk flow rate of 0.078 $m^{3} h^{-1}$ and heating level from 42 to $61^{\circ} \mathrm{C}$. The results show that the application of air pressure for microbubbles generation and pulsation type have a significant effect on fouling layer prevention for more while 105 minutes (the experimented time). For these reasons, the use of the two integrated techniques can progress thermal process of the plate heat exchanger. The optimum treatment for fouling deterrence is at applied air pressure of $0.6 \mathrm{MPa}$ and gradient pulsation, frequency with $0.16 \mathrm{~Hz}$ and two states of steadily, unsteady of 20 seconds and steady of 10 seconds, the fouling layer decreases by $76.5 \%$, and the maximum value of the overall heat transfer coefficient obtained is $9688.4 \mathrm{Wm}^{-2} \mathrm{~K}^{-1}$.

KEYWORDS: Heat treatment, fouling impact, heat transfer coefficient, dissolved air flotation, pulsed flow

1. Associate Professor, Agricultural Engineering Department, Faculty of Agriculture, Kafrelsheikh University, Egypt

2. Lecturer, Agricultural Engineering Department, Faculty of Agriculture, Kafrelsheikh University, Egypt 


\section{NOMENCLATURE}

A Heat transfer surface area, $\mathrm{m}^{2}$

LMTD Log mean temperature difference, $\mathrm{K}$

$\mathrm{C}_{\mathrm{n}} \& m$ Constants defined by Martin, 1996

$C_{p} \quad$ Specific heat transfer at constant pressure, $\mathrm{J} \mathrm{kg}^{-1} \mathrm{~K}^{-1}$

$d_{h} \quad$ Hydraulic diameter of stream channel, $\mathrm{m}$

$h \quad$ Film heat transfer coefficient, $\mathrm{Wm}^{-2} \mathrm{~K}^{-1}$

$m \quad$ Mass flow rate, $\mathrm{kgs}^{-1}$

Q Overhaul duty heat, $\mathrm{kJ}$

$R_{f} \quad$ Thermal fouling resistance, $\mathrm{m}^{2} \mathrm{KW}^{-1}$

â Corrugation depth, $m$

$\Lambda \quad$ Wavelength pitch, $\mathrm{m}$

$X \quad$ Dimensionless corrugation parameter

$t \quad$ Time of process, $\mathrm{s}$

$\mathrm{U} \quad$ Overall heat transfer coefficient, $\mathrm{Wm}^{-2} \mathrm{~K}^{-1}$

$v \quad$ Velocity of fluid, $\mathrm{ms}^{-1}$

WR Waviness ratio, dimensionless

S Heat exchanger effectiveness

$\Phi \quad$ The plate area enlargement factor, dimensionless

$\mathrm{L}_{\mathrm{p}} \quad$ Vertical plate length, measured between the upper and lower port holes, $\mathrm{m}$

$q \quad$ Volumetric flow rate, $\mathrm{m}^{3} \mathrm{~s}^{-1}$

Greek letters

$\eta \quad$ Dynamic viscosity, $\mathrm{kg} \mathrm{s}^{-1} \mathrm{~m}^{-1}$

th Thickness of heat transfer plate, $0.55 \times 10^{-3} \mathrm{~m}$ $k \quad$ Thermal conductivity, $\mathrm{Wm}^{-1} \mathrm{~K}^{-1}$

$\rho \quad$ Fluid density, $\mathrm{kgm}^{-3}$

$\omega \quad$ Angular frequency, $\operatorname{rad~s}^{-1}$

Dimensionless numbers

$N u=\frac{h d_{h}}{k}$ Nusslet number

$\operatorname{Pr}=\frac{\eta c_{p}}{k}$ Prandtl number

$R e=\frac{\rho v d_{h}}{\eta}$ Reynolds number

$S t=\frac{\tau . \eta}{d_{h}}$ Strouhal number

DAF Dissolved air flotation

$\mathrm{T} \quad$ Fluid temperature, $\mathrm{K}$

$j \quad$ Plate width between gaskets, $\mathrm{m}$

$n \quad$ The number of gaps of one side

$u$ Flow velocity, $\mathrm{ms}^{-1}$

$\tau \quad$ Characteristic process time, $\mathrm{s}$

$\tau_{c} \quad$ Convective time, $\mathrm{s}$

$\mathrm{U}(\mathrm{t}) \quad$ Overall heat transfer coefficient, at any time of process, $\mathrm{Wm}^{-2} \mathrm{~K}^{-1}$

$\mathrm{U}(0) \quad$ Overall heat transfer coefficient, at initial conditions, clean conditions, $\mathrm{Wm}^{-2} \mathrm{~K}^{-1}$

Superscripts and subscripts

d Deposition

end Final

fo $\quad$ Fouled

$\max \quad$ Maximum

o Oscillating

s Stationary

w Water (service fluid)

m Milk (product fluid) 


\begin{tabular}{|c|c|c|c|}
\hline$\theta$ & Contact angle, degree & $w i$ & water inlet \\
\hline$\beta$ & $\begin{array}{l}\text { Chevron corrugation inclination } \\
\text { angle, degree }\end{array}$ & $m i$ & milk inlet \\
\hline$\xi$ & Friction factor & $w o$ & water outlet \\
\hline$\Delta n$ & Pressure drop, $\mathrm{Nm}^{-2}$ & $m o$ & milk outlet \\
\hline
\end{tabular}

\section{INTRODUCTION}

T2 $\begin{aligned} & \text { eat exchangers are generally used for thermal processes of dairy } \\ & \text { products. Plate heat exchangers are used in a wide range in food } \\ & \text { industry due to many reasons such as a compact design, very }\end{aligned}$ large surface area per a unit volume which can be modified per requirement by increasing the number of plates and advances in material technology (Abu-Khader, 2012). Deposition on heat transfer surfaces causes an extremely problem. With an increase in processing temperatures, the deposit is formed quickly. The milk deposits are poor thermal conductors and restrict the fluid flow. Although a lot of investigations were conducted for fouling problem overcome, but it remains have some obstacles. To recognize the fouling problem, the contributing variables to fouling are categorized into four classes related to 1) Heat exchanger design, such as surface material and surface roughness (Barish and Goddard, 2013 and Huang and Goddard, 2015). 2) Process variables such as flow velocity and processing temperature (Bansal and Chen, 2006; Prakash et al., 2015 and Khaldi et al., 2015), the adhesion of foulant elements on the surfaces may be reduced at larger flow velocities. The shear forces induced on the surface can detach the fouling layer, which enhances heat transfer and mixing in the milk bulk that permits the protein aggregation in the milk rather than at the surface (Visser $\boldsymbol{e t}$ al., 1997). On the other hand at high turbulences the trap of protein aggregates in the fouling layer can be preferred, so that the regression dependence between velocity and deposition components is not always linearly, as in calcium phosphate more deposition occurs at high flow velocities (Andritsos et al., 2002). 3) Pretreatment variables such as preheating (Prakash et al., 2015) and 4) Milk variables, such as air content (Jeurnink, 1995 and Tirumalesh et al., 1997), seasonal variation and $\mathrm{pH}$ (Burton, 1967 and Grandison, 1988). Milk $\mathrm{pH}$ has a significance inverse relationship on the fouling rate (Hyslop and Fox, 
1981 and Skudder et al., 1986). The conflicting has occurred for many of these variables are dependent each on other, so some dependent variables are treated as independent variables. Plate heat exchangers have some limits about high velocities due to pressure drop considerations. Despite the turbulences are found due to the plates corrugations, fouling takes place. The major cause of deposition in plate heat exchangers is stagnation zones around the contact areas of plates, especially behind these contact points where there is no shear stress effects due to milk flowing. Moreover, the milk temperature is accumulated at these areas due to higher shear stress at upstream of the contact areas (Metwally and Manglik, 2004 and Zettler and Müller-Steinhagen, 2002). Several techniques were used for fouling solutions and plate heat exchanger improvements. Magnetic field treatment did not affect calcium phosphate fouling rates significantly and did not change the crystal forms of deposits, but it can enhance the membrane separation performance (Zin $\boldsymbol{e t}$ al., 2016). The fouling layer creation has not prevented totally by using the ultrasound energy, but the ultrasound energy of $1.2 \times 10^{5} \mathrm{~kW} /\left(\mathrm{m}^{2} \cdot \mathrm{min}\right)$ can delay the fouling rate (Lin and Chen, 2007). However, (Hotrum et al., 2015) investigate ultrasound potential to prevent bio-fouling of milk inoculated with $10^{3} \mathrm{CFU} / \mathrm{m} \ell$ thermo-resistant streptococcus (TRS) Streptococcus thermophilus, the ultrasound of $20 \mathrm{kHz}$ and $70 \mathrm{~W}$ produces a surface vibration magnitude in the range of 500-1200nm(inertial cavitation) can serve as a mechanism for bio-fouling prevention on plate heat exchanger surfaces, whereas, the acoustic effect at micro-streaming regime (non-inertial cavitation) was showed no significant impact on biofouling development. Microbubbles don't cogitate as an antifouling mechanism in plate heat exchangers, there is no literatures show the contribution of microbubbles in this field; Dissolved air flotation (DAF) has recently used as a pretreatment option for seawater and wastewater treatment, only a limited number of studies have been undertaken (Shutova et al., 2016 and Filho et al., 2016). Especially if these bubbles are under pressure with milk, it will achieve double benefits; one for milk sterilization under pressure as an efficient alternative to traditional thermal pasteurization with minimum impact on nutritional and sensorial properties (Espejo et al., 2014 and Andres et al., 2016); and the other for 
raising the shear stress on heat transfer surfaces of plate heat exchangers. The fluid velocity increases the shearing actions on deposit-fluid interface. High shear forces may erode the deposit layer, especially loose soot particles on heat transfer surfaces, if else the deposition involves diffusion or mass transfer, at higher velocities the diffusion toward the heat transfer surface will increase, if the concentration gradient is found. In cooling systems, where biofouling is taking place, higher velocities may enhance the nutrients availability at the heat transfer surface (Qureshi, 2004). The main aim of this study is to enhance the plate heat exchangers performance in milk concentration by fouling control and removal, and apprehends the precipitation of microbubbles in milk as a function of different levels of applied air pressure to hold-on tank of the milk and the involvement of milk hydrodynamics (pulsed flow), which is based on the effect of the sudden acceleration of the milk flow and consequently the fluctuation of the wall shear stress that endorse the creation of additional vortices around the contact points and therefore to enhance the process of fouling removal.

\section{MATERIALS AND METHODS}

The present investigation was carried out at the Animal Production Research Station, Sakha village, Kafr Elsheikh Governorate, Egypt during the summer season of the year 2016. The method used for microbubbles generation is known as dissolved air flotation (DAF) where air is dissolved into liquid at elevated pressure 0.4 to $0.5 \mathrm{MPa}$ and then unconfined through the decompression valve that directed to the plate heat exchanger. The average diameter of microbubbles generated is between 55 to $75 \mu \mathrm{m}$ (Edzwald, 2010 and Shutova et al., 2016).

\section{Experimentation}

The experimental setup is consisting of three insulated stirred tanks as heating water vessel equipped with $1 \mathrm{~kW}$ immersed electrical heater for heat energy supply integrated with a solar heating system (T1), milk product vessel that receives the processed milk (T2) and the hold-on milk vessel (T3). Plate heat exchanger is operated in countercurrent flow of milk to water heating sides. The applied plate heat exchanger (EXC) was connected to a heating unit and to the milk hold-on (saturator) vessel (T3). EXC is consisted of four plates. Plate material was from stainless 
steel and its dimensions were of 550X130mm with an effective heat transfer area of $0.094 \mathrm{~m}^{2}$. The operating parameters of the used plate heat exchanger are defined in Table 1. In the middle channel, the one path of foulant fluid (milk) and in the two outer channels the service fluid (two paths) was circulated. EXC was insulated (Asbestos), allowing for overall energy balances on the product as well as on the service side and the determination of overall heat transfer coefficients through temperature measurements. The supply unit was provided with heating water which was controlled automatically and kept at constant temperature using a solar heater (plate solar heater) and supplemental electrical aquarium heater. The heating water was pumped by a small centrifugal pump (P2, centrifugal pump, Askoll Mod. M 231 XP Cod. RC0083, 220-240VAC, $50 \mathrm{~Hz}, 0.2 \mathrm{~A}, 40 \mathrm{~W}$, Flow rate $20 \ell / \mathrm{min}$ ) at a constant flow rate that adjusted by two valves.

Table 1. Operating parameters definitions of the used plate heat exchanger

\begin{tabular}{|c|c|}
\hline Item & Magnitude \\
\hline Milk flow rate, $\mathrm{m}^{3} \mathrm{~h}^{-1}$ & $0.078 \pm 0.009$ \\
\hline $\begin{array}{l}\text { Fixed milk velocity, } v_{s} \text { and Reynolds } \\
\text { number, Re }\end{array}$ & $0.089 \mathrm{~ms}^{-1} \& 794$, respectively \\
\hline $\begin{array}{l}\text { Oscillating milk velocity, } v_{o} \text { and Reynolds } \\
\text { number, Reo }\end{array}$ & $\begin{array}{c}0.23 \text { and } 0.38 \mathrm{~ms}^{-1} \& 2070 \text { and } 3420, \\
\text { respectively }\end{array}$ \\
\hline Womersley number, W & 16.2 \\
\hline Milk inlet temperature, ${ }^{\circ} \mathrm{C}$ & $42 \pm 2$ \\
\hline Initial outlet temperature of milk, ${ }^{\circ} \mathrm{C}$ & $61 \pm 1$ \\
\hline Heating fluid flow rate, $\mathrm{m}^{3} \mathrm{~h}^{-1}$ & $1.56 \pm 0.2$ \\
\hline $\begin{array}{l}\text { Heating fluid velocity and Reynolds } \\
\text { number, Re }\end{array}$ & $0.87 \mathrm{~ms}^{-1} \& 1376$, respectively \\
\hline Heating fluid inlet temperature, ${ }^{\circ} \mathrm{C}$ & $63 \pm 1$ \\
\hline Heating fluid outlet temperature, ${ }^{\circ} \mathrm{C}$ & $62 \pm 1$ \\
\hline Volume of whey protein solution, $\mathrm{m}^{3}$ & 0.2 \\
\hline
\end{tabular}

Belt-driven air compressor (Power 2hp, air displacement 200l/min, air pressure $115 \mathrm{psi}=7.93 \mathrm{bar}$ ) applies four different air pressures of $0.1,0.2$, 0.3 and $0.6 \mathrm{MPa}$ on milk surface inside the milk hold-on or the saturator 
vessel, Figure 1. Two regulator valves are connected to the centrifugal pump outlet and inlet to control the water flow (heating medium) to the heat exchanger. Solenoid valve was used for milk saturator vessel effluent control. Three regimes were considered for milk releasing from the saturator tank with uniform pulsation (interruption time, the interval between two consequent open or close case of solenoid valve, is 7.5 seconds), gradient pulsation (gate valve open slowly in 20 seconds and its discharging is overlaying the discharge of solenoid valve) and absolutely without pulsation or continuous flow. The compressor was adjusted to maintain the pressure of milk saturator tank kept constant. For hydraulic fouling measurements, the manometer and mass flow meter were installed at the heat exchanger outlet, the drop in flow and pressure was used as an indicator for fouling increment in heat exchanger.

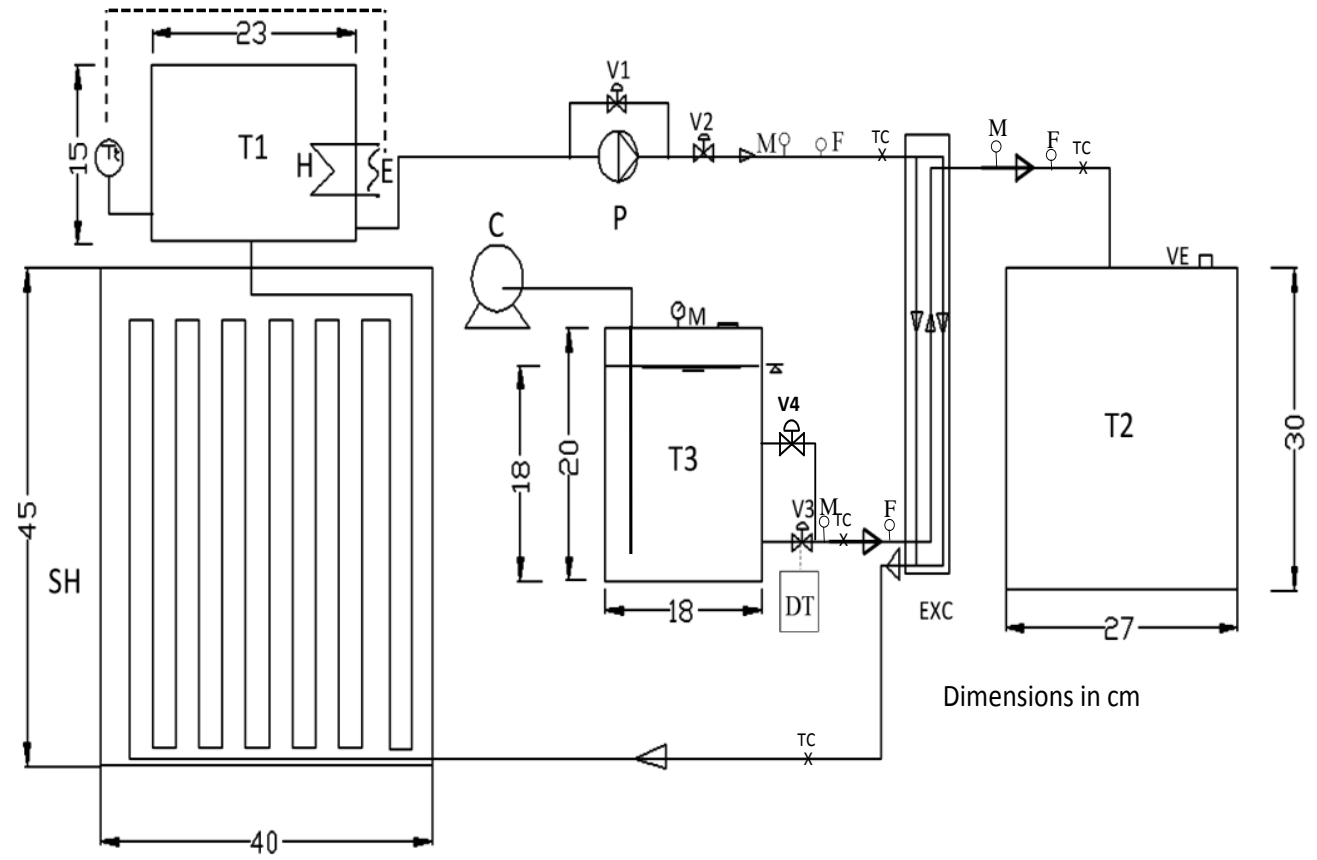

Figure 1. Experimental setup of the milk concentrator unit, EXC: plate heat exchanger, v3: solenoid valve with a microcontroller (DT) for uniform pulsation generation, P: centrifugal pump, T1: water heating vessel, T2: product vessel, T3: milk hold-on (saturator) vessel, C: air compressor, M: Manometer, H: aquarium electrical heater of 400W, E: electrical source connected with thermostat, v1 and v2 are control valves 
for flow regulation, v4: regulator gate valve overlaying with v3 for gradient pulsation creation, F: water flow meter, $\mathrm{SH}$ : plate solar heater with internal black polyethylene tubes, VE: venting aperture, TC: thermocouple sensor for temperature measurements at milk and water inlets and outlets

\section{Mean flow velocity and waviness ratio determination}

The pulsed flow controlled by programmed solenoid valve, the overlaid pulsed flow is recognized by the sum of two parts, mean fixed velocity and the oscillating velocity, the mean flow velocity for an oscillating interval is defined as reported by Augustina et al., 2010 and Boxleret al., 2014:

$$
\bar{v}=\frac{1}{t_{o}} \int_{0}^{t_{o}} v(t) d t
$$

Eqn 1

Where $v(t)=v_{s}+v_{o}(t)=v_{s}+v_{o, \max } \sin (\omega t)$

And the pulsation intensity can be quantified using the waviness ratio, WR, Equation 2 or using the Womersley number, $W$ as shown by Equation 3, that is defined as the ration of the pulsating flow frequency to the viscous effects:

$$
W R=\frac{v_{o, \max }}{v}
$$

Where $v_{o, \max }$ is the maximum oscillating velocity

$$
W=\left(\frac{\omega \rho}{\mu}\right)^{0.5} d_{h y}
$$

\section{Heat exchanger performance evaluation}

Heat transfer performance of the used plate heat exchanger is analyzed by the following correlations which were cited from Cunault et al., 2013; Li et al., 2013; Boxler et al., 2014 and Khaldi et al., 2015. Heat losses can be neglected; meanwhile the plate heat exchanger was insulated. The overhaul heat can be written as:

$$
\mathrm{Q}=\mathrm{Q}_{\mathrm{w}}=\mathrm{m}_{\mathrm{w}} \mathrm{c}_{\mathrm{p}, \mathrm{w}}\left(\mathrm{T}_{\mathrm{wi}}-\mathrm{T}_{\mathrm{wo}}\right)=\mathrm{Q}_{\mathrm{m}}
$$

At the average temperature of each fluid, heat transfer kinetics can be characterized by:

$$
\dot{\mathrm{q}}=\frac{\mathrm{Q}}{\mathrm{A}}=\mathrm{U}(\mathrm{t}) \times \operatorname{LMTD}(\mathrm{t})
$$




$$
\operatorname{LMTD}(\mathrm{t})=\frac{\left(T_{w i}-T_{m i}\right)-\left(T_{w o}-T_{m o}\right)}{\ln \left(\frac{\left(T_{w i}-T_{m i}\right)}{\left(T_{w i}-T_{m o}\right)}\right)} \quad \text { Eqn } 6
$$

And the effectiveness of heat exchanger can be calculated by:

$$
S=\frac{T_{m o}-T_{m i}}{T_{w i}-T_{w o}}
$$

Overall heat transfer coefficient and thermal fouling resistance determination

Thermal fouling resistance can be calculated from the overall heat transfer coefficient at the initial conditions (clean surface) and any further time of fouling. Film heat transfer coefficients are assumed to be constant for both sides of milk and water in plate heat exchanger; the thermal fouling resistance can be given by Equation 8 as reported by Boxler $\boldsymbol{e t}$ al., 2014:

$$
\mathrm{R}_{\mathrm{f}}(\mathrm{t})=\frac{1}{\mathrm{U}(\mathrm{t})}-\frac{1}{\mathrm{U}(0)}
$$

Eqn 8

To determine the influence of dissolved air flotation and pulsation, as steady state achieved for each experimental run, data can be acquired for each 5 minutes. Overall heat transfer resistance can be determined by calculating the resistances of the water and milk convective heat transfer, the thermal fouling resistances for both sides of plate and the thermal conduction through the plate, where the heat transfer surface area is constant, the overall thermal fouling resistance can be described by Boxler et al., 2014 as:

$$
\mathrm{R}_{\mathrm{f}}=\frac{1}{\mathrm{U}}=\frac{1}{\mathrm{~h}_{\mathrm{w}}}+\frac{1}{\mathrm{~h}_{\mathrm{m}}}+\frac{\mathrm{k}}{\mathrm{th}}
$$

Where, the film heat transfer coefficient of the water stream $\left(h_{w}\right)$ was constant during the experiment.

Generally $h_{w}$ and $h_{m}$ can be determined by calculating the Nusselt number from two different equations. Equations 10 and 11 are conferring to Martin, 1996.

$$
\mathrm{Nu}=\mathrm{h}_{\mathrm{w} \text { or } \mathrm{m}} \times \frac{d_{h}}{\mathrm{k}}=\operatorname{Pr}^{1 / 3}\left(\frac{\eta}{\eta_{\mathrm{m}}}\right)^{1 / 6} \mathrm{C}_{\mathrm{n}} \mathrm{Re}^{\mathrm{m}}
$$

Where $d_{h}$ is the hydraulic diameter of stream channel, $\mathrm{m}$, with the constants of $C_{n}=0.195$ and $m=0.692$ (Martin, 1996). 
PROCESS ENGINEERING

Or by

$$
\mathrm{Nu}=0.122 \operatorname{Pr}^{1 / 3}\left(\frac{\eta}{\eta_{\mathrm{m}}}\right)^{1 / 6}\left[\xi \operatorname{Re}^{2} \sin (2 \varphi)\right]^{0.374}
$$

$\eta$ is the viscosity, Pa.s

$\xi$ is the friction factor, can be described as:

$$
\xi=\frac{2 \cdot \Delta p \cdot d_{h}}{\rho \cdot u^{2} \cdot L_{p}}=\frac{2 \cdot \Delta p \cdot d_{h}{ }^{3} \rho}{\eta^{2} \cdot L_{p} \cdot \operatorname{Re}^{2}}
$$

$L_{p}$ is the vertical plate length, measured between the upper and lower port holes and $u$ is the superficial velocity as:

$$
\mathrm{u}=\frac{\mathrm{q}}{\mathrm{n} \times \mathrm{j} \times 2 \hat{\mathrm{a}}}
$$

Where; $n$ is the number of gaps of one side, $j$ is the plate width between gaskets, 2â is the corrugation depth and $q$ is the volumetric flow rate.

The hydraulic diameter can be defined as four times of the fluid volume divided by the surface area, resulting in:

$$
\mathrm{d}_{\mathrm{h}}=\frac{4 \mathrm{a}}{\phi}
$$

The plate area enlargement factor, $\phi$ due to plate corrugation that is defined as the ratio of the developed surface area to the projected area

$$
\phi=\frac{1}{6}\left\{1+\left[1+\left(\frac{2 \pi \hat{a}}{\Lambda}\right)^{2}\right]^{0.5}+4\left[1+\frac{1}{2}\left(\frac{2 \pi \hat{a}}{\Lambda}\right)^{2}\right]^{0.5}\right\}
$$

Where $X=\frac{2 \pi \hat{a}}{\Lambda}$ is called the dimensionless corrugation parameter, $\hat{a}$ is the amplitude sinusoidal corrugation, $\Lambda$ is the wavelength pitch of the corrugations.

(Eqn 4 in Martin, 1996), and a corrugation depth (2â) of $2.45 \times 10^{-3} \mathrm{~m}$, Chevron corrugation inclination angle $(\beta)$ of $65^{\circ}$ and corrugation wavelength $(\Lambda)$ of $10.8 \times 10^{-3} \mathrm{~m}$

Strouhal number that represents the ratio of characteristic process time (pulsation amplitude), $\tau$, to convective time (time of milk response due to pulsation effect), $\tau_{c}=\frac{d_{h}}{\eta}$, (Deen, 1998).

$$
S t=\frac{\tau \cdot \eta}{d_{h}}
$$

Eqn 16 


\section{RESULTS AND DISCUSSION}

\section{Milk flow patterns in the plate heat exchanger}

The first flow pattern developed is a sinusoidal pressure pulsation profile, Figure 2A. The pressure drop owe to the plate's corrugation, manifolds and the internal distributer does not affect significantly the pressure profile of plate heat exchanger at outlet almost are identical at inlet and outlet. By the movement of solenoid valve (open and close), the sinusoidal pressure profile was created, called uniform pulsation. Automatic gate valve was installed in parallel to the solenoid valve open gradually until all the milk flow through it to generate gradient pulsation, as shown in Figure 2B. After the gate valve is opened, the vibration is damping and gradually dissipating. Figure $\mathbf{3}$ shows the corresponding values of waviness to the applied pressure of the air in the saturator tank. As air pressure increases in the saturator tank from 0.1 to $0.6 \mathrm{MPa}$, the waviness ratio raises from $2.1 \pm 0.57$ to $4.3 \pm 0.64$.

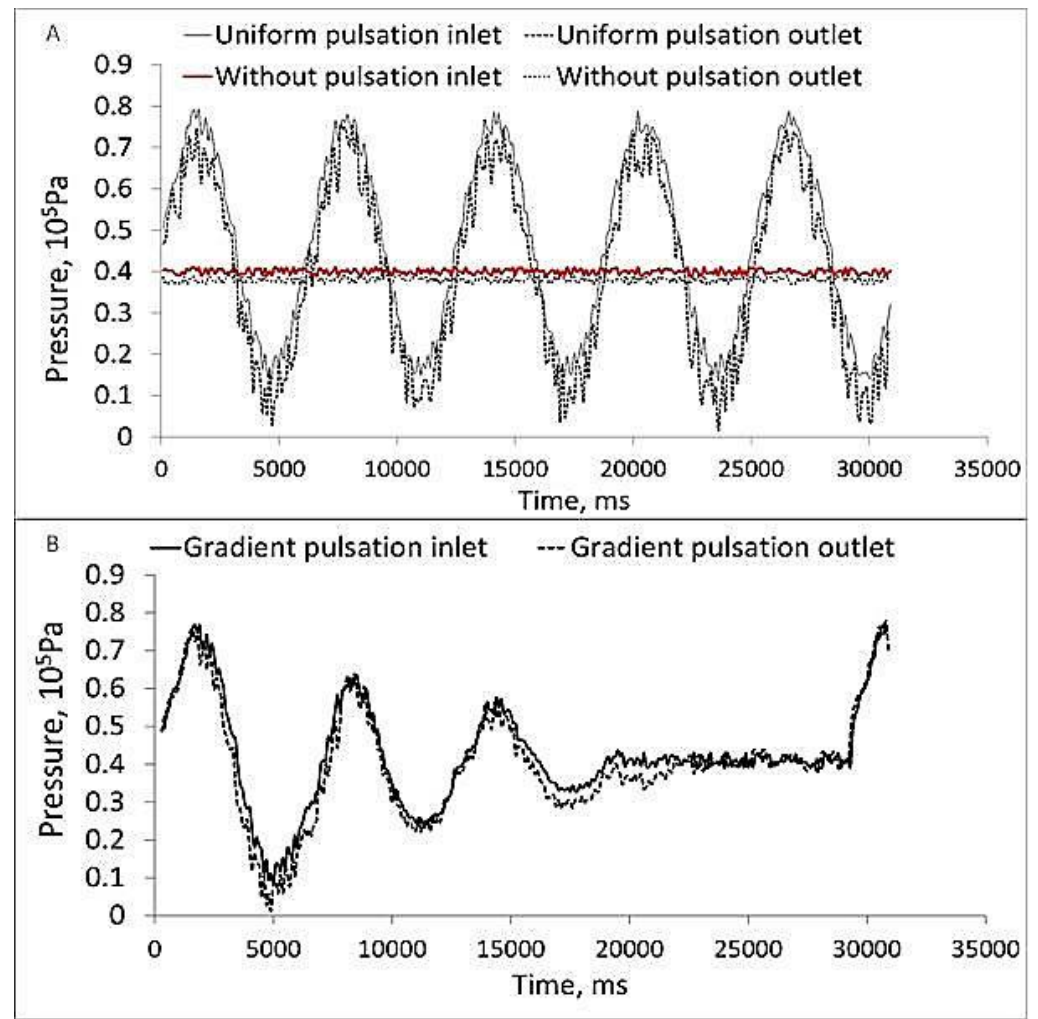

Figure 2. Pressure profile for (A) uniform and without pulsation flow (B) gradient pulsation flow of milk at Strouhal number of $0.536(0.6 \mathrm{MPa})$ 


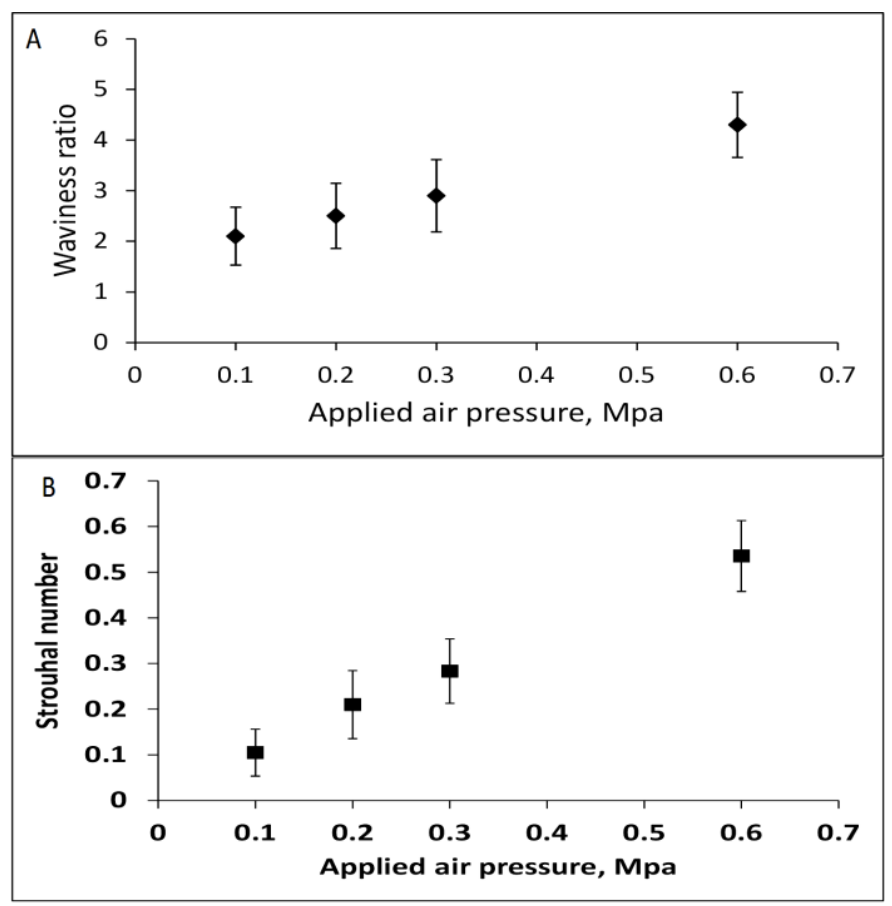

Figure 3. The effect of applied air pressure in the saturator tank on waviness ratio (A) and its corresponding values of Strouhal number (B) under uniform pulsation condition

\section{Heat exchanger performance evaluation}

\section{Overall heat transfer coefficient versus process time}

The plate heat exchanger performance was evaluated for all treatments, Figures 4 and 5. Log mean temperature difference, effectiveness and overall heat transfer coefficient were used as performance indicators. Data was collected for 105 minutes of exchanger running for steady state settlement. Figure 4 illustrates that, at the treatment of applied air pressure of $0.1 \mathrm{MPa}$ and without pulsation effect, the value obtained of $\log$ mean temperature difference is $6.8 \pm 1.0 \mathrm{~K}$, effectiveness of $24.755 \pm 3.880$ and overall heat transfer coefficient was of $2423.45 \pm 627.99 \mathrm{Wm}^{-2} \mathrm{~K}^{-1}$.

\section{Overall heat transfer coefficient at different waviness ratios}

Overall heat transfer coefficient rises from $4142 \pm 482.97$ to $7804.40 \pm 816.02 \mathrm{Wm}^{-2} \mathrm{~K}^{-1}$ as waviness ratio increases from 2.1 to 4.3 and increases from 7978.8 to $9688.4 \mathrm{Wm}^{-2} \mathrm{~K}^{-1}$ as waviness ratio increases from 2.2 to 4.2 for uniform and gradient pulsation, respectively, Figure 5. It 
can be noticed that the gradient pulsation improves the overall heat transfer coefficient compared to the without pulsation and uniform pulsation flow conditions. Several investigations on heat transfer of an oscillated flow in flat channels or pipes/ducts concluded that the flow pulsation intensified heat and mass transfer (Mackley et al., 1990; Ni et $a l ., 2003$ and Chang and Shiau, 2005).

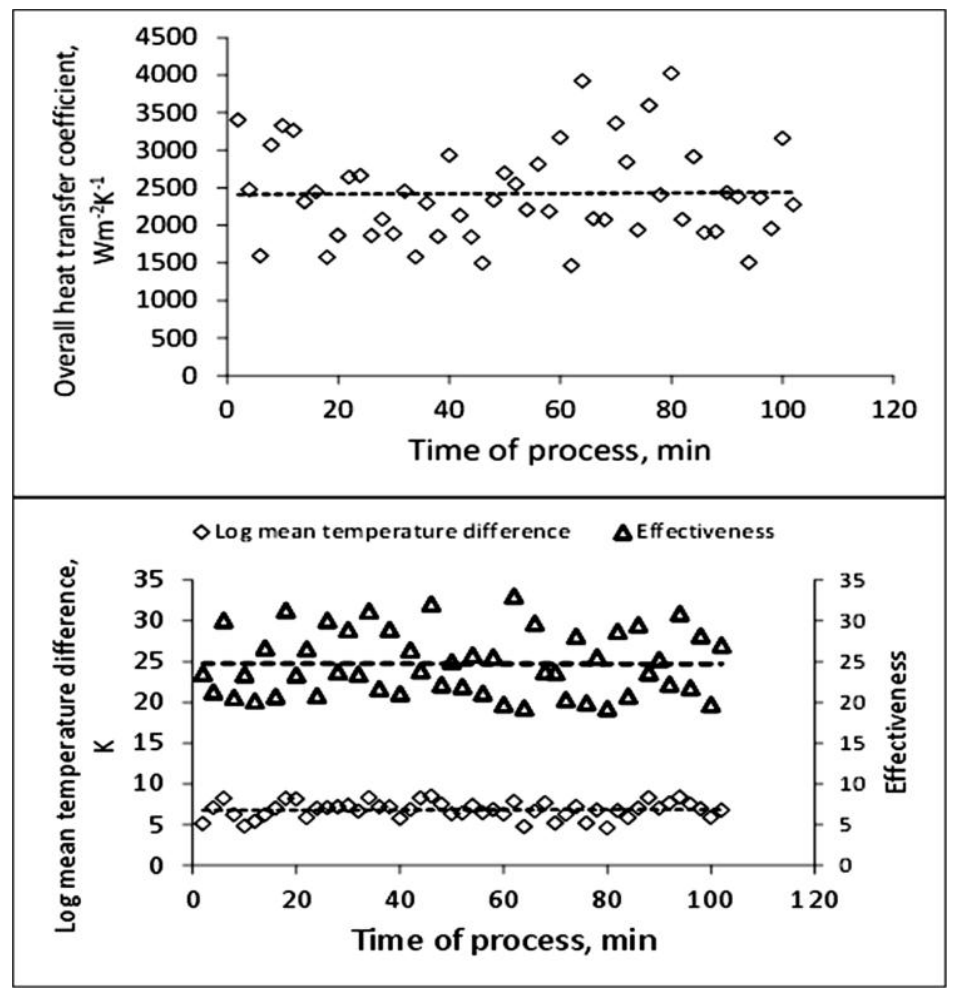

Figure 4. Heat exchanger performance at applied air pressure of $0.1 \mathrm{MPaand}$ without pulsation treatment, the trend line is used only to show the mean value

The increase of heat transfer has been due to eddies and vortices formation that diminish the creation of the laminar boundary layer and reduce this layer thickness behind baffles and the recirculation flow on the downstream side of the baffles aids to the fluid behind the baffle is transported back into the bulk (Chen and Chen, 1998).

In other words, the changes of the boundary layer and the flow circulation enhancement in stagnation zones in the plate heat exchanger, in which both temperature and concentration profiles change is created, will affect 
the deposition rate. It was found more materials were deposited at outlet regions where the wall temperature is close to the temperature of heating medium. By the observation, the formation of deposits differed over the plates of the heat exchanger and consequently the deposition shrinkages with flow pulsation application. The thermal fouling resistance is not observed at the flow distribution region for the effect of the oscillation flow in this area. Due to the high temperature difference at inlet about $21 \mathrm{~K}$, this difference is highly sufficient for thin fouling layer formation. Also this layer was noticed under different patterns of pulsed flow and is translated into thermal fouling resistance.

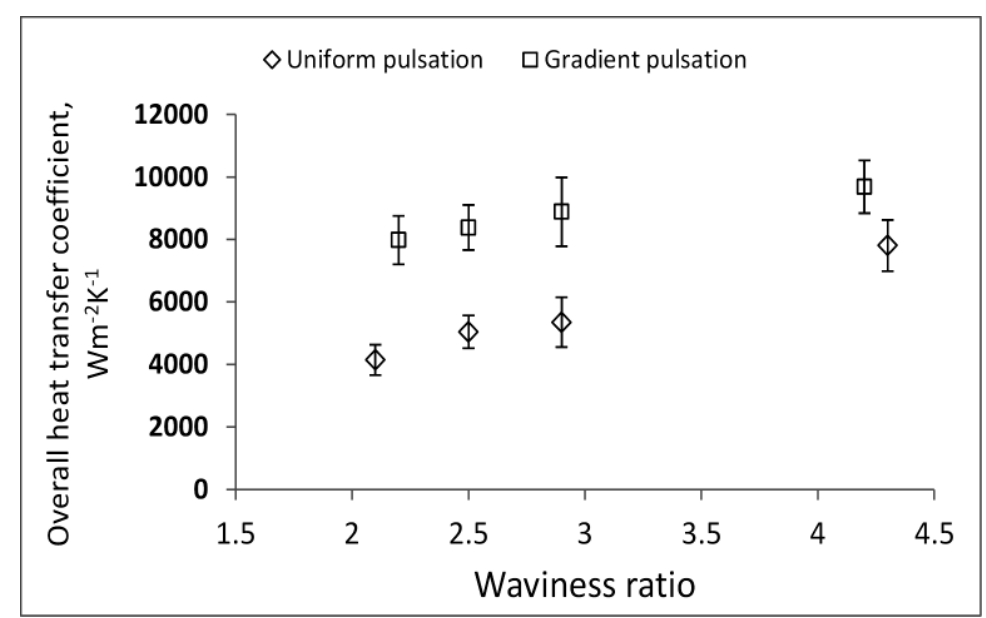

Figure 5. Overall heat transfer coefficient under uniform and gradient pulsation conditions for different waviness ratios

\section{Thermal fouling resistance}

The influence of different flow pulsation patterns and applied air pressure in the saturator tank (waviness ratio) on thermal fouling resistance, the fouling curves are shown in Figure 6. It was observed that the thermal fouling resistance, at without pulsation conditions (fixed flow), raises over time to be $3.93 \times 10^{-5}, 3.97 \times 10^{-5}, 4.48 \times 10^{-5}$ and $3.72 \times$ $10^{-5} \mathrm{~m}^{2} \mathrm{KW}^{-1}$ for applied air pressures of $0.1,0.2,0.3$ and $0.6 \mathrm{MPa}$, respectively. For lower pulsation amplitude at air pressure of $0.1 \mathrm{MPa}$, Figure 6A, and at the uniform pulsation mode, the deposit started growing in lower rate than the gradient pulsation mode that increased rapidly to a value close to the value of without pulsation mode, while the 
thermal fouling resistance in the uniform pulsation mode reached less than the half value of $1.77 \times 10^{-5} \mathrm{~m}^{2} \mathrm{KW}^{-1}$. Thermal fouling resistance fluctuations in the uniform pulsation mode are due to the oscillating shear stress that removes periodically the deposits attached the plates. These results are similar to that obtained by Boxler et al., 2014.

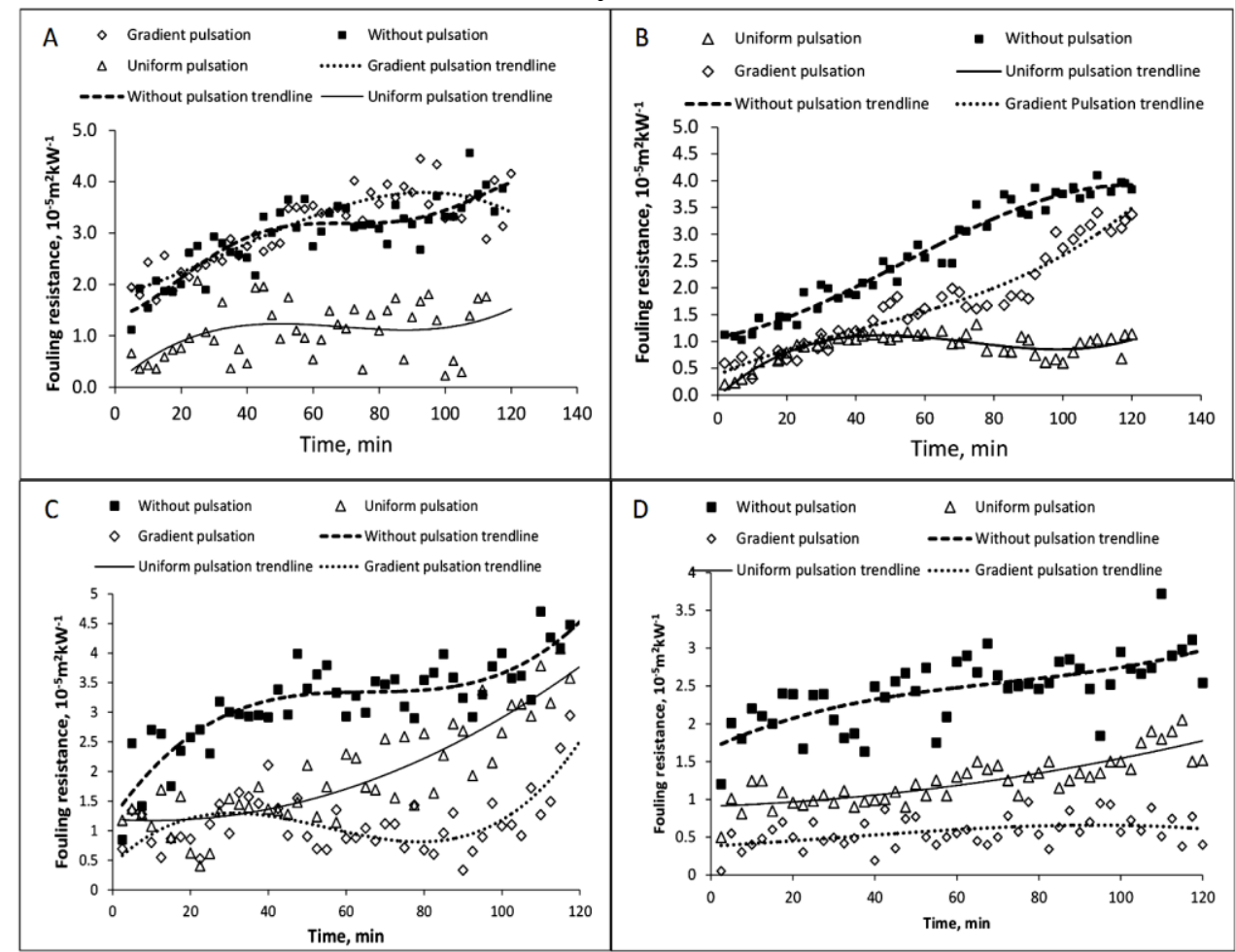

Figure 6. Thermal fouling resistance for different pulsating conditions, at different applied air pressures of $0.1 \mathrm{MPa}(\mathrm{A}), 0.2 \mathrm{MPa}(\mathrm{B}), 0.3 \mathrm{MPa}(\mathrm{C})$ and $0.6 \mathrm{MPa}(\mathrm{D})$

Further experiments were done on thermal fouling resistance for optimization under 0.2, 0.3 and $0.6 \mathrm{MPa}$ as shown in Figure 6B, 6C and 6D. The results were altered from that obtained at lower applied pressure $(0.1 \mathrm{MPa})$. In contrary the thermal fouling resistance of gradient pulsation mode is lower than that of the uniform pulsation. It is observed that the gradient pulsation is beginning to be lower than the thermal fouling resistance of without pulsation mode. As applied air pressure increases to $0.6 \mathrm{MPa}$, the thermal fouling resistance has a significant irreversible increase for the uniform pulsation due to milk with high air content has 
lower density that helps for fouling prevention and encourages heat transfer by microbubbles. Microbubbles generate a lot of turbulences and vortices inside corrugated heat transfer surface of plate heat exchanger. Besides, the contact areas have the advantage of microbubbles that can turn around these points and clean all deposits using the hydrodynamics of collisions and implosions (inertial cavitation) of microbubbles, these results are similar to those obtained by Gondrexon $\boldsymbol{e t}$ al., 2015 which use the ultrasonic to remove calcium carbonate fouling layer in double tube heat exchangers, but they cannot determine the main responsible for this removal; is by the cavitation bubbles implosion (inertial cavitation) near to heat transfer surface or by the intense acoustic micro-streaming (noninertial cavitation)? In this investigation, it is obviously that the bubbles implosion has a direct effect on fouling removal that increases with the raising of applied air pressure. The most important observation at the applied air pressure of $0.6 \mathrm{MPa}$ is that the thermal fouling resistance of gradient pulsation reach a constant value and almost not to change. But the uniform pulsation nearly starts to increase after 60 minutes. The final thermal fouling resistance magnitudes achieved for both gradient and uniform pulsation were of $0.72 \times 10^{-5}$ and $1.25 \times 10^{-5} \mathrm{~m}^{2} \mathrm{KW}^{-1}$, respectively.

\section{CONCLUSIONS}

The fouling experiments were done to investigate the effect of different modes of discharging flow of the milk, which is hold under different pressurized air, from the milk saturator tank on milk fouling of plate heat exchanger used for milk consolidation process. The three different modes of milk flow to the plate heat exchanger are uniform pulsed flow, gradient pulsed flow and without pulsation. Four different levels of applied air pressures of $0.1,0.2,0.3$ and $0.6 \mathrm{Mpa}$ were considered. Waviness levels were formed by the aids of the different applied air pressures, the waviness ratio raises from $2.10 \pm 0.57$ to $4.30 \pm 0.64$ as applied air pressures increases from $0.1 \mathrm{MPa}$ to $0.6 \mathrm{MPa}$. The different levels of air pressures generate four corresponds values of milk flow waviness. Pulsed flow supported with pressurized air technique was effective in reducing fouling and showed a reliable application in plate heat exchangers in milk industries. Heat transfer progress was also achieved under flow pulsation 
due to the increase in wall shear stress around the contact places changing the hydrodynamic conditions of fouling zones. The maximum value of heat transfer coefficient is 7804.4 and $9688.4 \mathrm{Wm}^{-2} \mathrm{~K}^{-1}$ that has been achieved at waviness ratio of 3.9 for both uniform and gradient pulsation, respectively. The lowest value of thermal fouling resistance was achieved at Strouhal Number of 0.536 . With the increasing in pulsation amplitude or the waviness or the Strouhal number, by increasing applied air pressure to the milk saturator tank, the thermal fouling resistance decreases by $49.03 \%$ and $76.5 \%$ for uniform and gradient pulsation, respectively at Strouhal Number of 0.536 .

\section{REFERENCES}

Abu-Khader, M. M. 2012. Plate heat exchangers: Recent advances. Renewable and Sustainable Energy Reviews, 16 (4): 1883-1891.

Andres, V.; M. Villanueva and M. Tenorio. 2016. Influence of high pressure processing on microbial shelf life, sensory profile, soluble sugars, organic acids, and mineral content of milk- and soysmoothies, LWT. Food Science and Technology, 65: 98 - 105.

Andritsos, N.; S. G.Yiantsios and A. J. Karabelas.2002.Calciumphosphate scale formation from simulated milk ultrafiltrate solutions.Food and Bioproducts Processing, 80 (C4): 223-230.

Augustina, W.; T. Fuchsa; H. Foste; M. Scholer; J. Majschak and S. Scholl. 2010. Pulsed flow for enhanced cleaning in food processing. Food and Bioproducts processing, 88: 384-391.

Bansal, B. and X. D. Chen. 2006. Effect of temperature and power frequency on milk fouling in an ohmic heater. Food and Bioproducts Processing, IChemE, 84 (C4): 286-291.

Barish, J. A. and J. M. Goddard. 2013. Anti-fouling surface modified stainless steel for food processing. Food and Bioproducts Processing, IChemE, 91: 352-361.

Boxler, C.; W. Augustin and S. Scholl. 2014. Composition of milk fouling deposits in a plate heat exchanger under pulsed flow conditions. Journal of Food Engineering, 121: 1-8.

Burton, H. 1967. Seasonal variation in deposit formation from whole milk on a heated surface. J. Dairy Res., 34: 137-143.

Chang, T. S. and Y. H. Shiau.2005. Flow pulsation and baffle's effects on the opposing mixed convection in a vertical channel. International Journal of Heat and Mass Transfer, 48 (19-20): 4190-4204. 
Chen, Z. D. and J. J. J. Chen. 1998. Local heat transfer for oscillatory flow in the presence of a single baffle within a channel. Chemical Engineering Science, 53 (17): 3177-3180.

Cunault, C.; C. H. Burton and A. M. Pourcher. 2013. The impact of fouling on the process performance of the thermal treatment of pig slurry using tubular heat exchangers. Journal of Environmental Management, 117: 253-262.

Deen, W. M. 1998.Analysis of Transport Phenomena. Oxford University Press, New York.

Edzwald, J. K. 2010. Dissolved air flotation and me. Water Research, 44: $2077-2106$.

Espejo, G. G. A.; M. M. Hernandez-Herrero; B. Juan and A. J. Trujillo. 2014. Inactivation of Bacillus spores inoculated in milk by Ultra High Pressure Homogenization. Food Microbiology, 44: 204-210.

Filho, J. A.; A. Azevedo; R. Etchepare and J. Rubio. 2016. Removal of sulfate ions by dissolved air flotation (DAF) following precipitation and flocculation. International Journal of Mineral Processing, 149: $1-8$.

Gondrexon, N.; L. Cheze; Y. Jin; M. Legay; Q. Tissot; N. Hengl; S. Baup; P. Boldo; F. Pignon and E. Talansier. 2015. Intensification of heat and mass transfer by ultrasound: Application to heat exchangers and membrane separation processes. Ultrasonics Sonochemistry, 25: 40-50.

Grandison, A. S. 1988. Ultra-High-Temperature Processing of Milk: Seasonal Variation in Deposit Formation in Heat Exchangers. J. Soc. Dairy Techol., 41: 43-49.

Hotrum N. E.; P. D. Jong; J. C. Akkerman and M. B. Fox. 2015. Pilot scale ultrasound enabled plate heat exchanger - Its design and potential to prevent biofouling. Journal of Food Engineering, 153: $81-88$.

Huang K. and J. M. Goddard. 2015. Influence of fluid milk product composition on fouling and cleaning of Ni-PTFE modified stainless steel heat exchanger surfaces. Journal of Food Engineering, 158: $22-29$.

Hyslop, D. B. and P. F. Fox. 1981. Heat stability of milk: interrelationship between assay temperature, $\mathrm{pH}$ and Agitation. J. Dairy Res., 48: 123-129. 
Jeurnink, T. J. M. 1995. Fouling of heat exchangers by fresh and reconstituted milk and the influence of air bubbles. Milchwissenschaft, 50: 189-193.

Khaldi, M.; P. Blanpain-Avet; R. Guérin; G. Ronse; L. Bouvier; C. André; S. Bornaz; T. Croguennec; R. Jeantet and G. Delaplace. 2015. Effect of calcium content and flow regime on whey protein fouling and cleaning in a plate heat exchanger. Journal of Food Engineering 147: 68-78.

Li, W.; H. Li; G. Li and S. Yao. 2013. Numerical and experimental analysis of composite fouling in corrugated plate heat exchangers. International Journal of Heat and Mass Transfer, 63: 351-360.

Lin, S. X. Q. and X. D. Chen. 2007. A laboratory investigation of milk fouling under the influence of ultrasound. Trans. IChemE, Part C, Food and Bioproducts Processing, 85 (C1): 57-62.

Mackley, M. R.;G. M. Tweddle and I. D. Wyatt.1990. Experimental heat transfer measurements for pulsatile flow in baffled tubes. Chemical Engineering Science, 45 (5): 1237-1242.

Martin, H. 1996. A theoretical approach to predict the performance of Chevron-type plate heat exchangers. Chemical Engineering and Processing, 35: 301-310.

Metwally, H. M. and R. M. Manglik. 2004. Enhanced heat transfer due to curvature induced lateral vortices in laminar flows in sinusoidal corrugated-plate channels. International Journal of Heat and Mass Transfer, 47 (10-11): 2283-2292.

Ni, X.; M. R. Mackley; A. P. Harvey; P. Stonestreet; M. H. I. Baird and N. V. Rama Rao. 2003. Mixing through oscillations and pulsations - a guide to achieving process enhancements in the chemical and process industries. Chemical Engineering Research and Design, 81 (3): 373-383.

Prakash, S.; O. Kravchuk and H. Deeth. 2015. Influence of pre-heat temperature, pre-heat holding time and high-heat temperature on fouling of reconstituted skim milk during UHT processing. Journal of Food Engineering, 153: 45-52.

Qureshi, B. A. 2004. Design, rating and exergy analysis of evaporative heat exchangers. M. Sc. thesis, King Fahd University of Petroleum and Minerals, Dhahran, Saudi Arabia Kingdom, pp: 214. 
Shutova, Y.; B. L. Karna; A. C. Hambly; B. Lau; R. K. Henderson and P. Le-Clech. 2016. Enhancing organic matter removal in desalination pretreatment systems by application of dissolved air flotation. Desalination, 383: 12-21.

Skudder, P. J.; B. E. Brooker; A. D. Bonsey and N. R. Alvarez-Guerrero. 1986. Effect of $\mathrm{pH}$ on the formation of deposit from milk on heated surfaces during UHT Processing. J. Dairy Res., 53: 75-87.

Tirumalesh, A.; R. H. G. Rao and H. M. Jayaprakash. 1997. Fouling of heat exchangers. Indian Journal of Dairy and Biosciences, 8: 41-44.

Visser, H.; Th. J. M. Jeurnink; J. E. Schraml; P. J. Fryer and F. Delplace. 1997. Fouling of heat treatment equipment. Bulletin of the International Dairy Federation, 328: 7-31.

Zettler, H. U. and H. Müller-Steinhagen. 2002. The use of CFD for the interpretation of fouling data in PHEs. In: Müller-Steinhagen, H.; M. R. Malayeri and P. Watkinson (Eds.), Heat Exchanger Fouling Fundamental Approaches and Technical Solutions. PUBLICO Publications, Essen, pp: 125-135.

Zin, G.; F. M. Penha; K. Rezzadori; F. L. Silva; K. Guizoni; J. C. C. Petrus; J. V. Oliveira and M. D. Luccio. 2016. Fouling control in ultrafiltration of bovine serum albumin and milk by the use of permanent magnetic field. Journal of Food Engineering, 168: 154159.

\section{الملخص العربي}

تحسين معدل الحرارة المنتقلة خلال المبادلات الحرارية أثناء عملية تركيز الحليب

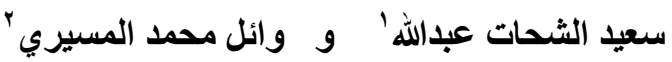

تستخدم المبادلات الحرارية عموماً للمعاملات الحرارية لمنتجات الألبان، حيث الهابل أن استخدام

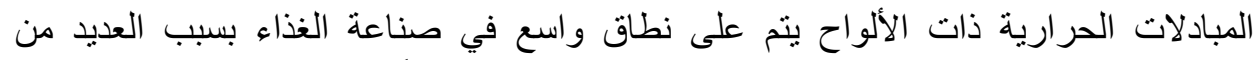

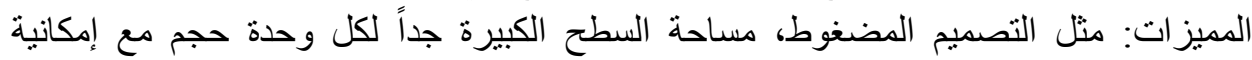

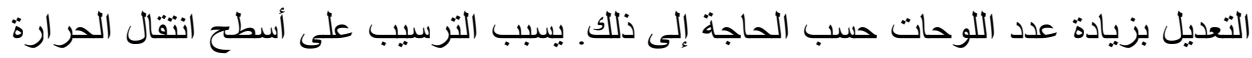

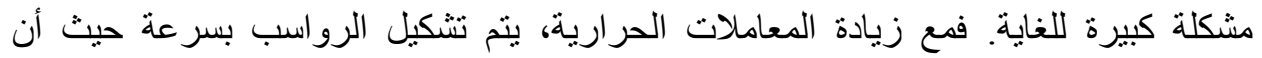

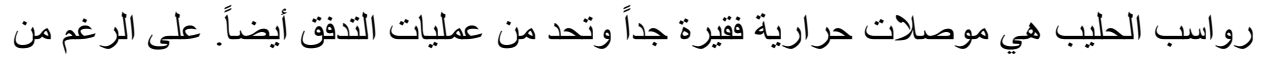

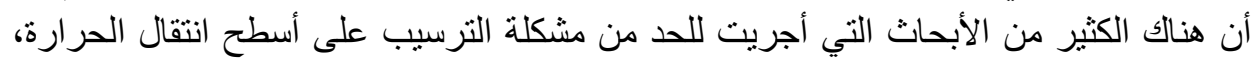

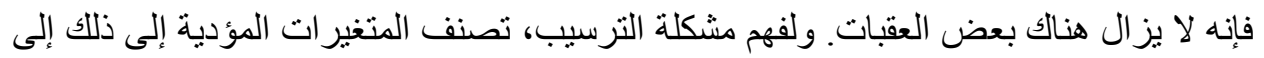

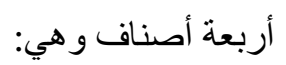

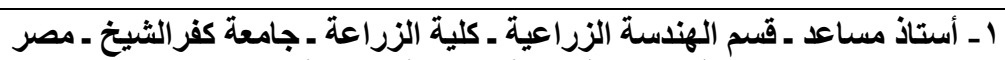

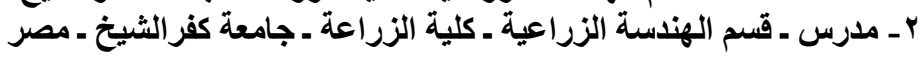




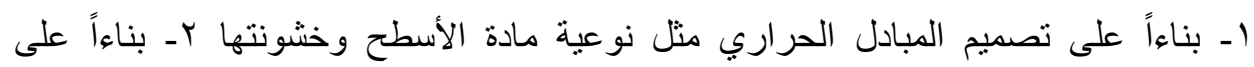

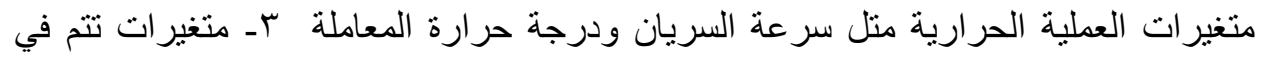

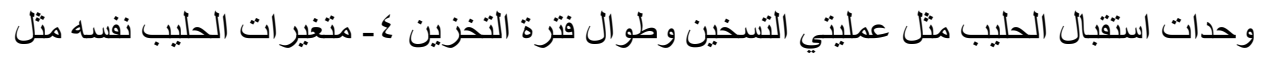

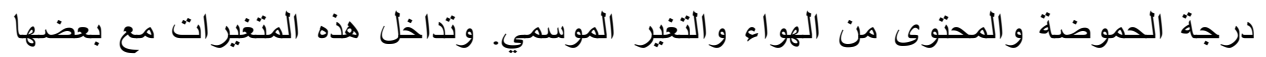

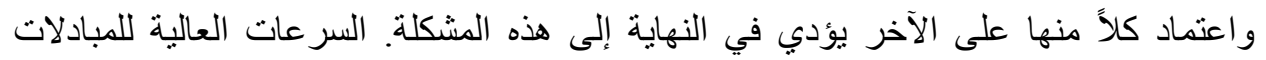

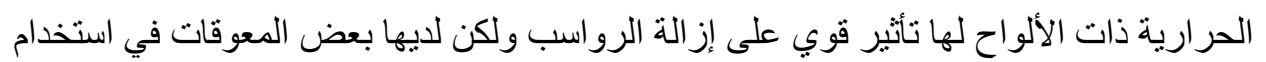

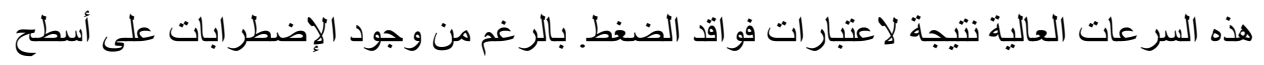

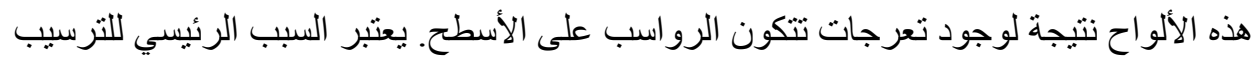

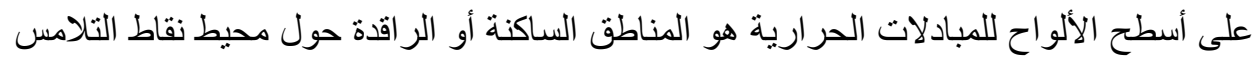

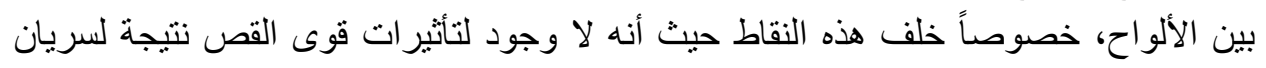

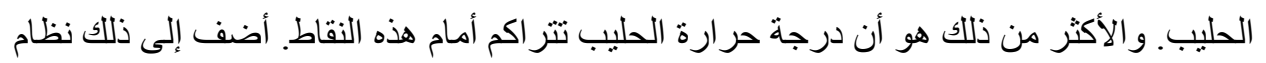

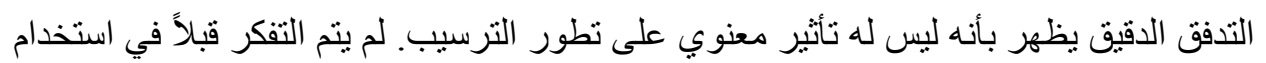

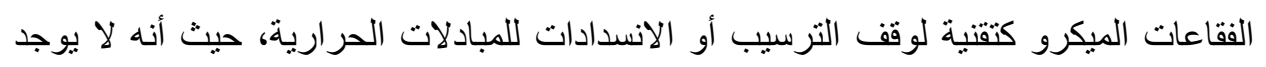

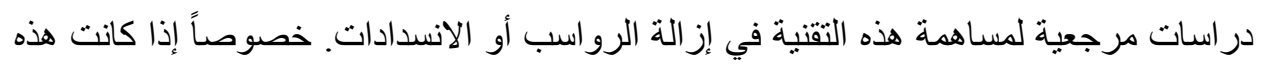

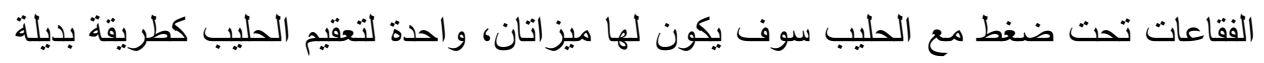

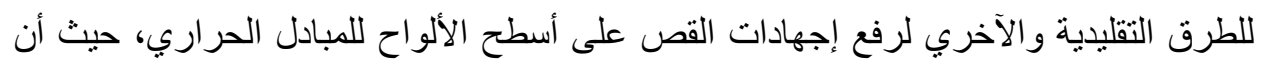

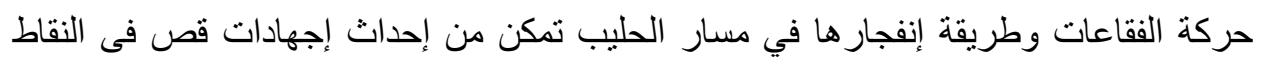

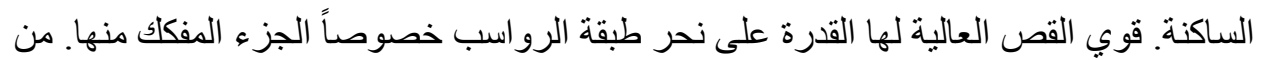

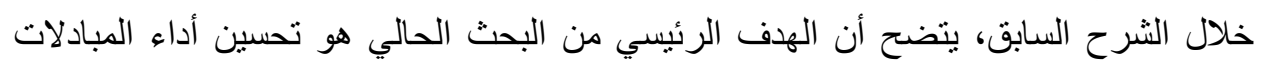

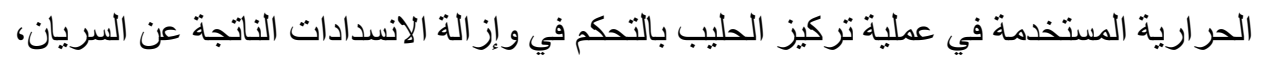

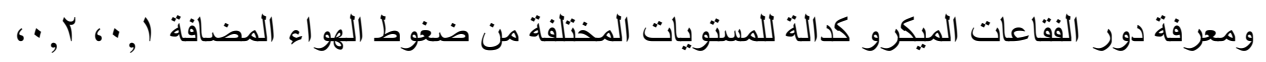

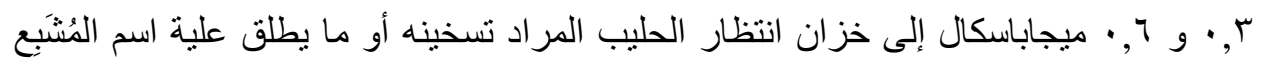

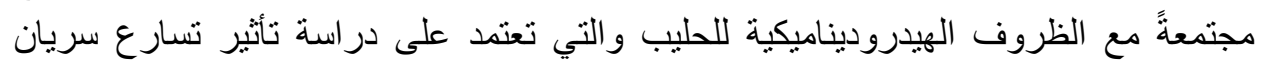

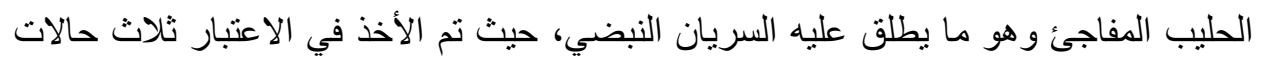

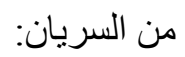

الأولى هي السريان النبضي المتماثل والثانية السريان النبضي المنحدر و الثالثة بدون تأثير للنبض على الإطلاق و هو ما يسمى بالسريان التقليدي.

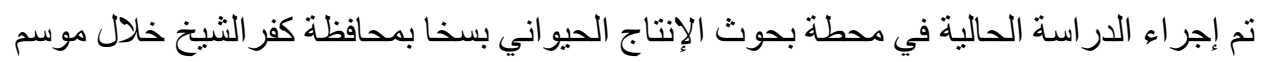

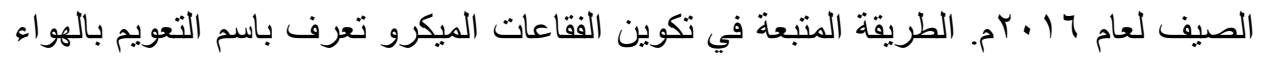

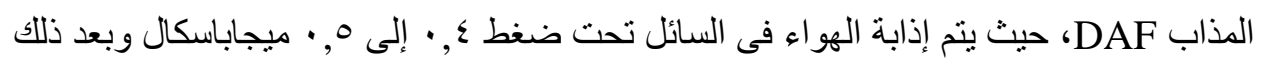

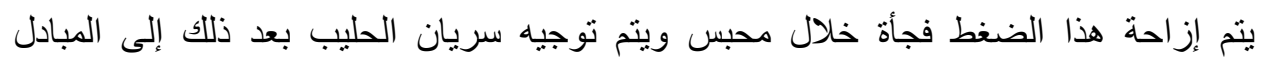

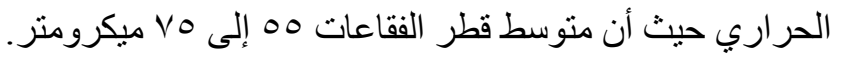




\section{تكونت الإعدادات التجريبية من ثلاث خز انات معزولة كالآتي:}

الأول خزان الماء المستخدم كوسيط للتسخين والمعد به سخانات كهربية ا كبلووات و المتصل أيضاً بوحدة تسخين للماء بالطاقة الثمسية للحصول على درجة حر ارة بـ درجة لمئوية.

و الثاني خزان ناتج الحليب الساخن الخارج من المبادل الحراري على درجة حرارة זٓ درجة

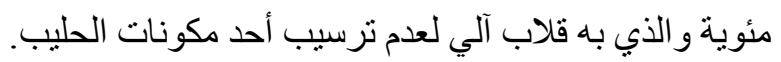

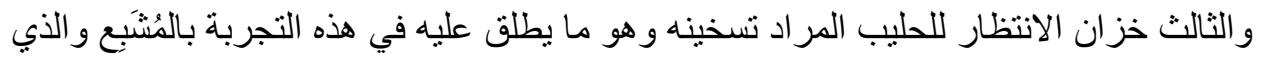

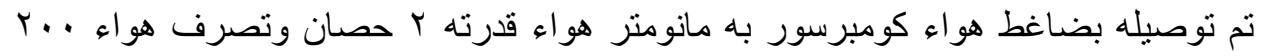

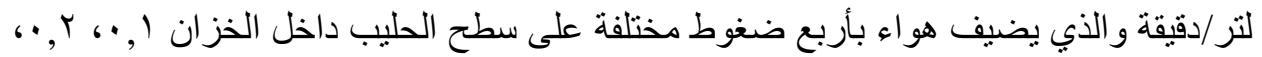

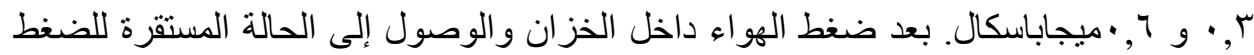

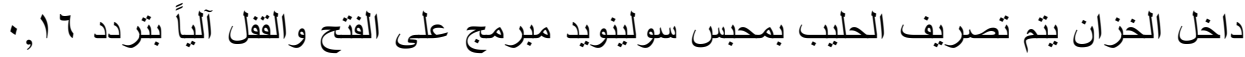

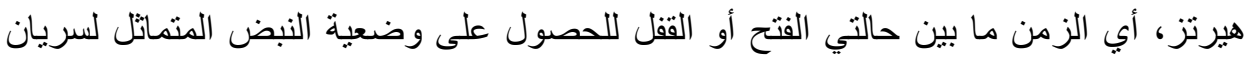

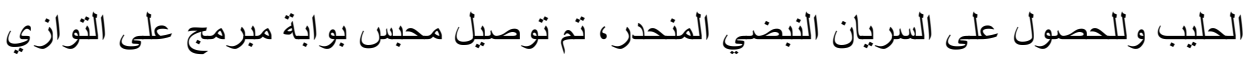

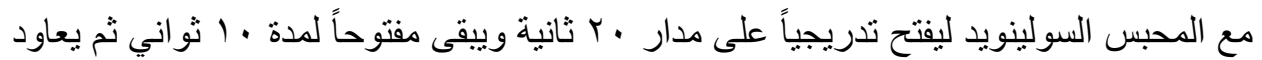

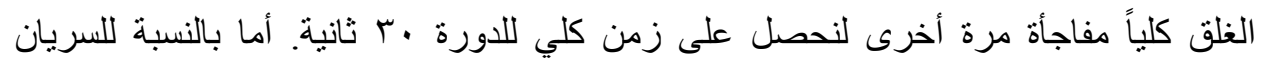

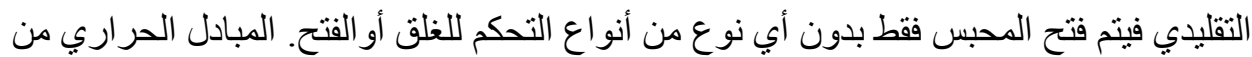
النوع المتاعكس المستخدم مصنوع من الصلب المقاوم للصدأ وأبعاده هي لـ

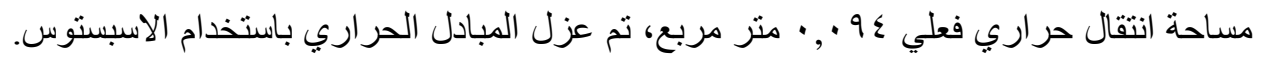

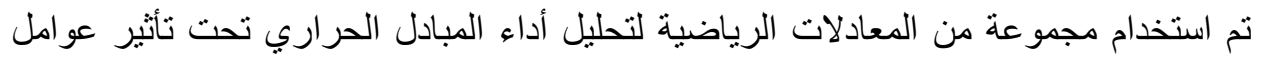
الدر اسة وتحديد مقاومة الإنسداد الحراري.

من أهم النتائج المتحصل عليها أن استخدام تقنيتي التعويم بالهو اء المذاب مع السريان النبضي له له

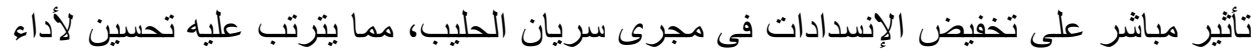

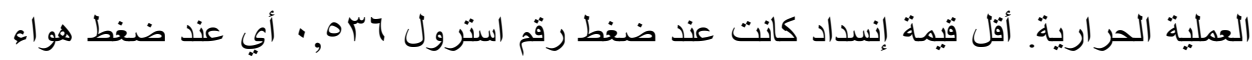

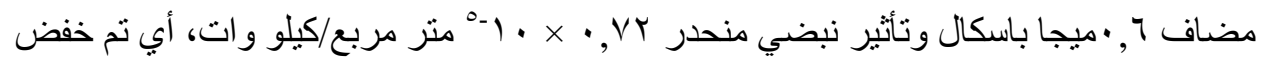

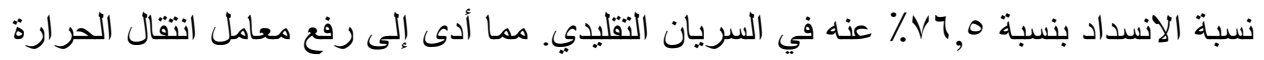

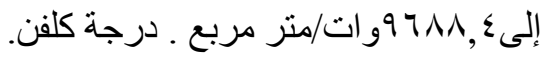

